\title{
Transplante de médula ósea para niños en el Perú
}

\author{
Children 's bone marrow transplantation in Peru
}

\author{
Milton José Max Rodríguez Zúñiga ${ }^{1, a}$ \\ Universidad Nacional Mayor de San Marcos, Lima, Perú. \\ a Médico Cirujano.
}

An Fac med. 2014;75(3):269-70 / doi: http://dx.doi.org/10.15381/anales.v75i3.9784

\section{SEÑOR EDITOR:}

El trasplante de médula ósea (TMO) es un procedimiento costoso y complejo por el cual la médula ósea sana de un donante se infunde dentro del flujo sanguíneo de un receptor, a quien se le destruyó su médula ósea con radioterapia y/o quimioterapia. El TMO fue reportado por primera vez en animales, en 1951, y exitosamente en humanos, en 1968, en los Estados Unidos de América (EUA). Este se ha convertido en un tratamiento promisorio, especialmente en las leucemias linfoides, que permite remisiones y sobrevida hasta en $90 \%$ de los casos, dependiendo del estadio de la enfermedad ${ }^{(1)}$.

Los datos de morbilidad y mortalidad en el país demuestran que las leucemias, especialmente la leucemia linfoblástica aguda (LLA), son los principales problemas oncológicos en nuestra población pediátrica. El Instituto Nacional de Enfermedades Neoplásicas (INEN) comunica que las leucemias linfoides representan la octava neoplasia maligna más frecuente en nuestro país, con 325 casos en el 2011. En niños, tanto de 0 a 14 años como de 15 a 19 años, la leucemia linfoide se muestra como la neoplasia maligna más frecuente, con 144 y 34 casos en el año 2004, respectiva- mente ${ }^{(2)}$. En los datos oficiales de mortalidad informados por el Ministerio de Salud del Perú (MINSA), la LLA es la causa 21 de mortalidad a nivel general, con 180 fallecimientos en el 2012; esta es la primera causa de mortalidad por enfermedades neoplásicas en la población pediátrica menor de 14 años, con 61 fallecimientos en el 2012, muy por delante de los tumores de cerebro, con 31 muertes en el mismo año ${ }^{(3)}$.

Según Eckrich y col. ${ }^{(4)}$, el TMO ha crecido desproporcionalmente entre los países clasificados por el Banco Mundial como de altos y bajos ingresos. El Centro Internacional de Investigación de Trasplante de Sangre y Médula (CIBMTR, en inglés) señala que en EUA se realizan más de 300 TMO por 10 millones de personas al año, mientras que en América Latina menos de 50, con solo un total aproximado de 1000 TMO registrados al año. Argentina y Brasil fueron los primeros países de la región en implementar este procedimiento en 1981, mientras que el Perú recién lo hizo en 1995. En total existen 55 centros de TMO en América Latina, encontrándose la mayor cantidad en Brasil (20 centros), Argentina (14 centros) y México (7 centros) ${ }^{(4)}$. Estos datos revelan la gran deficiencia del estado peruano en implementar este procedimiento en su sistema de salud, en comparación con otros países de la región; y, de la misma manera, la gran deficiencia de América Latina en comparación con los EUA.

Debido al problema de salud pública que representa esta entidad, el MINSA inició en el 2012 las coordinaciones para la creación del Servicio de TMO del INEN para adolescentes y adultos, dentro del marco del Plan Esperanza ${ }^{(5)}$. Sin embargo, este aún no es una realidad; nuestro país carece de guías o protocolos para el TMO, de registros de TMO practicadas y de falta de accesibilidad para la población pediátrica a los hospitales del MINSA.

Con todos estos datos, se hace urgente la necesidad del MINSA para que acelere la implementación del programa de TMO accesible para la población pediátrica oncológica del país, cuya principal causa de morbilidad y mortalidad se reduciría sustancialmente y brindaría altas probabilidades de curación y remisión en este grupo de la sociedad.

\section{REFERENCIAS BILIOGRÁFICAS}

1. Inaba H, Greaves M, Mullighan CG. Acute lymphoblastic leukaemia. Lancet. 2013;381(9881):194355. doi: 10.1016/S0140-6736(12)62187-4. 
2. INEN. Neoplasias malignas más frecuentes 2014 [obtenido 201410 Junio]. Disponible en: http://www.inen.sld.pe/portal/estadisticas/datosepidemiologicos.html.

3. MINSA. Mortalidad por cancer maligno por grupos de edad MINSA; 2014 [actualizado 11 junio 2014; citado 201411 junio]. Disponible en: http://www. minsa.gob.pe.

4. Eckrich M, Pasquini M. Hematopoietic cell transplantation in Latin America. Hematology. 2012;17 Suppl 1:S189-91. doi: 10.1179/102453312X133
36169157059.

5. Salazar MR, Regalado-Rafael R, Navarro JM, Montanez DM, Abugattas JE, Vidaurre T. [The role of the National Institute of Neoplastic Diseases in the control of cancer in Peru]. Rev peru med experim salud publica. 2013;30(1):105-12.

Carta recibido el 24 de julio de 2014.

Autofinanciamiento
No conflicto de intereses.

El trabajo no ha sido presentado en congreso o tesis alguna.

Correspondencia:

Dr. Milton Rodríguez Zúñiga

Dirección: Calle 2 M-12 Los Girasoles, La Molina,

Lima.

Celular: +51950111539

Correo electrónico: Milton_rz@hotmail.com 